\title{
Western Ontario大学・BLWTL*における雪工学研究
}

\section{1.はじめに}

筆者は，1988年10月末から1989年 1 月末にかけて の約 3 ケ月間, カナダ・オンタリオ州にあるWestern Ontario大学のBLWTL（写真－1）におい てvisiting researcherとして滞在する機会を得た。 この研究所は後述するように，風工学に関する専門 の研究所として発足し, 以来世界の風工学研究を リードしてきているが, 研究スタッフ並びに研究施 設の充実に伴い, 現在では風工学に限らず幅広い研 究が行なわれている。雪工学研究も重要な研究領域 の 1 つである。

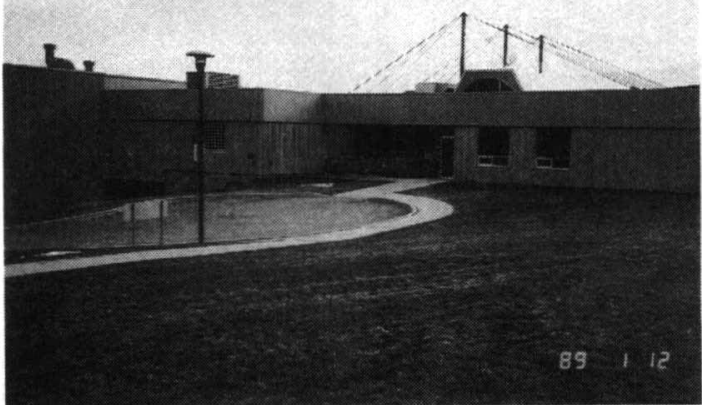

写真-1 BLWTL外観

筆者は, 滞在期間中, 主として「大スパン屋根の 耐風性」という雪工学とはかなり掛け離れた研究を行 なっていたが, その傍ら本研究所におりる雪工学研究 に関する情報む収集したので，その概要を紹介する。
植松康 ${ }^{* *}$

\section{BLWTL の 概 要}

本研究所は, 風工学に関する専門の研究機関とし て, 1965年に発足し, その後, 数多くの先駆的研究 が行われてきた。発足当初の研究内容は主として

1) 自然風の特性に関する研究

2 ）構造物の設計における風荷重の合理的評価に関 する研究

3）構造物の風に対する静的・動的応答に関する研 究

であった。特に，現在研究所のDirectorであある Davenport教授は, 風荷重並びにそれによる構造物 の応答の評価に対し, 確率論手法を展開した。その 成果は, 高く評価され, 現在世界各国における構造 物の耐風設計規準・指針等の基礎となっている。

設立当初建設された大型境界層風洞（BLWT I ; 長さ $32 \mathrm{~m}$, 幅 $2.4 \mathrm{~m}$, 高さ $1.5 \sim 2.1 \mathrm{~m}$, 最大風速約 15 $\mathrm{m} / \mathrm{s}$, 図一 1 ) は, トロントのCN towerやニュー ヨークのWorld Trade Center など数多くの構 造物・建築物の設計に用いられた。

その後の研究成果並びに研究スタッフの充実に伴 い, 研究領域屯拡大し, 1984年には多目的の新しい 境界層風洞（BLWT II） が完成した。その概要を 図一 2 に示す。現在てれら 2 台の大型境界層風洞及 び 2 台の小型風洞を用いて種々の研究が行われてい る。研究内容を本研究所のパンフレットより引用し, 表ー 1 に示す。これら広範囲の研究を表一 2 に示した

* The Boundary Layer Wind Tunnel Laboratory の略

** 東北大学工学部助手・工博

(本稿受理 : 1989年 2 月 1 日) 


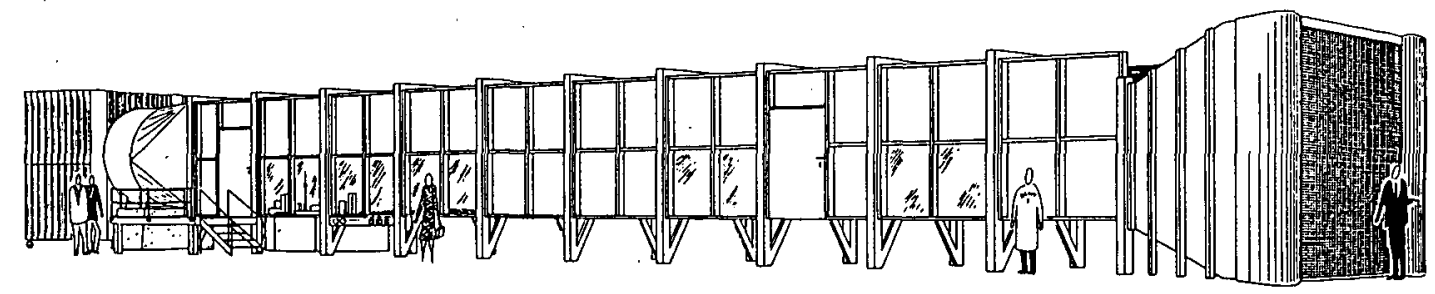

LENGTH - 33m (108ft); WIDTH - 2.4m (8ft); HEIGHT - 2.1 to $1.5 \mathrm{~m}$ t7 to $5 \mathrm{ft}) ;$ MAXIMUM SPEED - $55 \mathrm{~km} / \mathrm{hr}(35 \mathrm{mph})$

\section{図 - $1 \quad$ BLWT I の 概要}

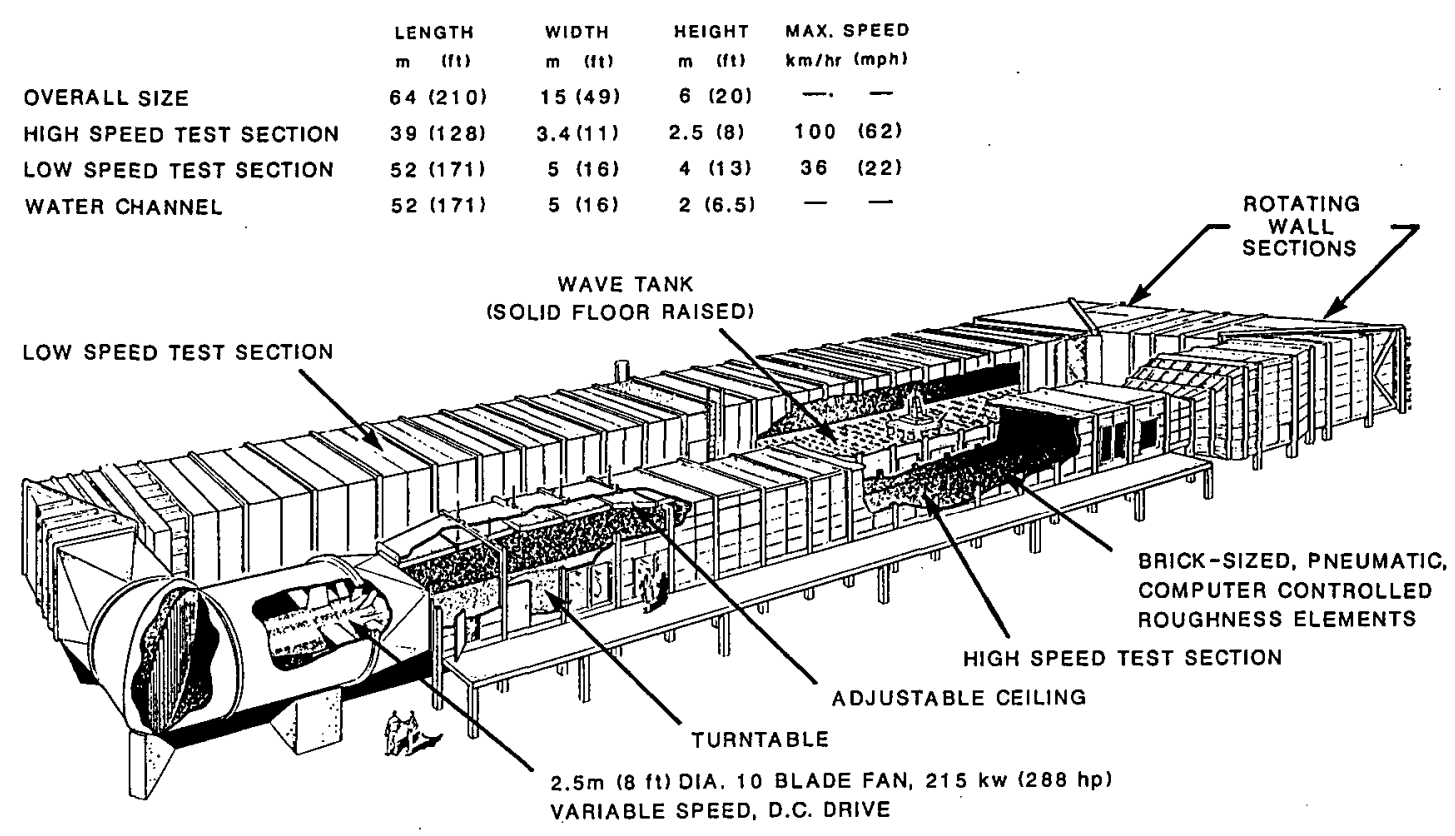

\section{図ー2 BLWT II の概要}

教授, 助教授を中心に，20名近くの教育・研究スタッ フ並びに約15名の大学院生・研究生が䘕なっている。

\section{BLWTLにおける雪工学研究}

カナダは，言うまでもなく，国全体が積雪寒冷 地であり，ソ連・北欧諸国と共に雪水研究の先進国 ですある。雪は市民生活にも大きな影響を及ばし， 工学的にあ重要な問題である。本研究所では，先 に述べたように，風工学が研究の中心課題である が，表一 1 からあ分かるように，雪工学の諸問題 屯 Davenport教授やIsyumov助教授を中心に研究
が進めら机ている。特に，Isyumov助教授1),4), 6), $\left.\left.\left.{ }^{8)}-12\right), 14\right), 16\right)$ は, 設計用雪荷重の評価に対して統計 ・確率論的アプローチを展開し，その研究はカナダ のBuilding Code (1985) ${ }^{17)}$ の基礎となっている。 近年, 日本でもこの種の研究が盛んに行なわ扎るよ うになったが，その先駆的研究と言えよう。

雪と風に関連する問題で, 工学的に特に重要と思 われるものには，

1 ) 雪水の付着したケーブル等の空力不安定振動

$$
\text { (ギャロッピング) }
$$

2）地ふぶき

3 ）吹きだまり

が挙げられる。本研究所で屯, これらの問題に対し， 
表一 1 BLWTLにおける研究

SIGNIFICANT RESEARCH AND
ENGINEERING STUDIES . . . .

\section{Wind Effects on Buildings}

- determination of stresses, accelerations and sway • pressures on exterior glass and cladding $\bullet$ internal pressures and their effects - dynamic loads using an ultra-sensitive balance $\bullet$ wind loading on low buildings $\bullet$ influence of wind on air infiltration, heating and ventilation ...

Other Structures: Bridges, Towers, etc.

- dynamic cross-wind response of chimneys $\bullet$ aerodynamic derivatives for dynamic response of long span bridges • dynamics of guyed towers $\bullet$ dynamics of large inflated structures - dynamic response of transmission lines....

\section{Environmental Problems}

- local wind conditions for pedestrian comfort, etc. • dispersion of pollutants and chimney location - snow loading on roofs $\bullet$ drifting and depositon of snow $\bullet$ influence of wind breaks in agriculture and forestry ... Wind and Wave Interaction

- wind/wave effects on offshore structures - mooring and behaviour of ships in stormy seas $\bullet$ wind-induced iceberg drift ....

\section{Other Dynamic Problems}

- dynamics of foundations - prediction of structural damping $\bullet$ reliability of structures under wind and earthquake - seismic regionalization of Canada....

Wind Climate Studies

- statistical treatment of hurricane winds $\bullet$ topographic studies for wind flow over complex terrain $\bullet$ risk from tropical cyclones....

Wind Energy

- performance of wind energy machines in turbulent wind • siting and influence of topography....

Transportation

- ride qualities of rapid transit vehicles in strong winds helicopter and helipad operations....

\section{表ー 2 BLWTLの研究・教育スタッフ}

$\begin{array}{ll}\text { Director, Professor } & \text { Dr. A.G. Davenport } \\ \text { Manager, Assoc. Prof. } & \text { Dr. N. Isyumov } \\ \text { Research Directors, } & \\ \text { Professor } & \text { Dr. M. Novak } \\ \text { Assoc. Prof. } & \text { Dr. D. Surry } \\ \text { Professor } & \text { Dr. B.J. Vickery }\end{array}$

境界層風洞を用いた研究が為されている ${ }^{13), 15), 18) ， ~}$ 19), 21), 22) (写真一 2 )。現在, 特に風洞実験におけ る実現象の適切なモデル化に関心が注がれているよ うである。

図- 2 に示すように, BLWTI の低速部には, wave tankが装備されており，乙れを利用して，船舶や海 洋構造物に関する研究もさかんに行なわれている。 雪水に関連してュニークな研究としては, 風による 流水の運動に関する実験的研究 ${ }^{3)}$, 20) がある。

本文の最後にこれまでに出版された雪氷関連の論 文並びに報告書のリストを付録として載せた。学位 論文（博士・修士）及び報告書以外の論文について

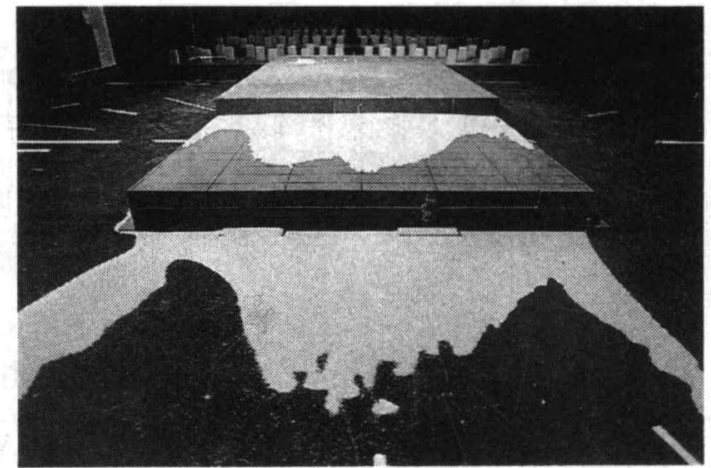

(a) 模型雪の埋積パターン（風下側より見たもの）

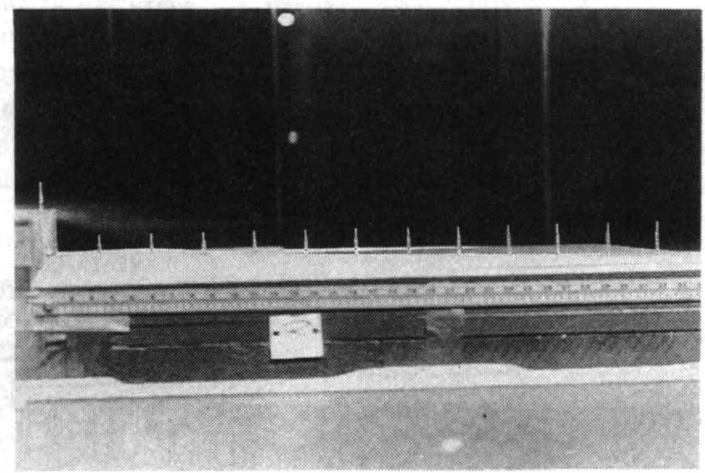

(b) 低層棟上の流れ方向堆積分布

写真一 2 セットバックのある建物の屋根上積雪 シミュレーション（Mr. Mikitiuk提供）

は, 別刷りが多数用意されている。下記宛に文書で 申し込めば無料で送付してくれるので, 積極的に利 用されたい。

Dr. N. Isyumov又はMr. M. J. Mikitiuk

The Boundary Layer Wind Tunnel Laboratory Faculty of Engineering Science

The University of Western Ontario London, Ontario N6A 5B9, CANADA

\section{4.おわりに}

本文は，筆者の短い滞在期間中に得た情報に基つ いて書かれたものである。従って，不十分な点む 多々あると思われるが，御容赦願いたい。日本にお ける今後の雪工学研究の発展に少しであ役立てば幸 いである。 
資料を快く提供してくれたWestern Ontario大 学BLWTLのスタッフ各位, 並びに，筆者にBL WTL滞在の機会を与えてくれてた東北大学・杉村 義広教授並びに山田大彦助教授に㳭く感謝の意を表 する。

\section{付録 論文・報告書リスト}

\section{(A) 学位論文 (博士, 修士)}

1. N. Isyumov, An approach to the prediction of snow loads, Ph. D. thesis, University of Western Ontario, 1971.

2. M. J. Mikitiuk, Effects of snow hazard on transportation, M. E. Sc. thesis, University of Western Ontario, 1978.

3. K. A. McTaggart, Physical modeling of wind-induced iceberg drift, M. E. Sc. thesis, University of Western Ontario, 1986.

\section{(B) 報告書}

4. N. Isyumov and M. Mikitiuk, Climatology of snowfall and related meteorological variables with application to roof snow load specifications, Faculty of Engineering Science Research Report BLWT-2, 1976.

5. M. Mikitiuk and N. Isyumov, Results of questionnaire on snow clearing operations and snow hazard, Faculty of Engineering Science Research Report BLWT-1, 1980.

6. M. Mikitiuk and N. Isyumov, Climatological summary of snowfall, rainfall and temperature for selected Canadian locations, Faculty of Engineering Science Research Report BLWT-3, 1980.

7. D. Surry, C. Hyslop and G. Lythe, A study of wind loads on the ice pond roof structure, Prudential "Enerplex" Project, Princeton, New Jersey, Faculty of Engineering Science Research Report BLWT SS11, 1983.
8. N. Isyumov, S. Helliwell and M. Mikitiuk, Estimates of snow loads for the proposed McCormick Place Extension, Chicago, Illinois, Faculty of Engineering Science Research Report BLWT--SS34, 1984.

9. A. G. Davenport, N. Isyumov, M. Mikitiuk, W. Heagy, S. Helliwell and D. Daw, A study of the action of wind and snow for the DOME, Toronto, Ontario, Faculty of Engineering Science Research Report BLWT-SS32, 1985.

\section{(C) 雑誌,シンポジゥム等での発表論文}

10. N. Isyumov and A. G. Davenport, A probabilistic approach to the prediction of snow loads, Canadian Jour. of Civil Eng., Vol. 1, No. 1, 1974, pp.28-49.

11. N. Isyumov, Snow and wind load considerations for arena structures, Canadian Soc. for Civil Eng., Ont. Region, Regional Seminar on the Restoration of Existing Buildings - Arena Structures, London, Ont., Nov. 24, 1977, pp.14.1-14.4.

12. N. Isyumov and M. Mikitiuk, Climatology of snowfall and related meterological variables with application to roof snow load specifications, Canadian Jour. of Civil Eng., Vol. 4, No. 2, 1977, pp. 240-256.

13. M. Novak, A. G. Davenport and H. Tanaka, Vibrations of towers due to galloping of iced cables, Jour. Eng. Mech. Div., ASCE, Vol. 104, No. EM 2, 1978, pp.457-473.

14. N. Isyumov, Roof snow loads; their variability and dependence on climatic conditions, Structural use of wood in adverse environments (Ed : R. W. Meyer and R. M. Kellog), New York, Van Nostrand Reinhold Company, 1982, pp.365-384.

15. A. G. Davenport, Combined loading of ice and wind on guyed towers, 2nd International Workshop on Atmospheric Icing of Struc- 
tures, Trondheim, Norway, June, 1984.

16. N. Isyumov, M. Mikitiuk and A. G. Davenport, Snow loads on roofs, 12 th Congress Int. Assoc. for Bridges and Structural Eng., Sept. 3-7, Vancouver, B. C., 1984 , pp. $859-866$.

17. National Building Code of Canada 1985 , 雪荷重に関する項目

Supplement, pp.7-20, Commentary H, pp. $203-218$.

18. A. G. Davenport, The static and dynamic behaviour of guy cables under the loading of ice and wind, Canadian Congress of Applied Mechanics, June 2-7, London, Ont., 1985.

19. A. G. Davenport, Interaction of ice and wind loading on guyed towers, 3rd International Workshop on the Atmospheric Icing of Structures, Vancouver, B. C., May 6-8, 1986.
20. K. A. McTaggart and A. G. Davenport, Wind/wave tank tests of drifting iceburg models, Polartech '86, Helsinki, Finland, Oct. 27-29, 1986.

21. N. Isyumov, M. Mikitiuk and P. Cookson, Wind tunnel modeling of snow driftingapplications to snow fences, Multidisciplinary Approach to Snow Engineering, Santa Barbara, California, July 10-15, 1988.

22. M. Mikituik and N. Isyumov, Variability of snow loads on large-area flat roofs, Multidisciplinary Approach to Snow Engineering, Santa Barbara, California, July 10-15, 1988.

23. N. Isyumov and M. Mikitiuk, Wind tunnel model simulations of snow accumulation in the aerodynamic influence of buildings and other bluff bodies. The 6th U. S. National Conference on Wind Engineering, 1989. 